\section{COMPOSITION OF THE MESODERM.}

UNDER the title 'Al'chiblast and parablast,' Waldeyer has published a long article (Arch. mikrosk. anat., xxii. 1), in which he reviews chiefly His's views concerning the origin of the connective tissue, bloodvessels, etc.; but he also considers several cognate questions.

His's investigations have been confined to vertebrates, but he apparently believes that his view is also applicable to invertebrates. Professor His distinguishes two distinct groups of tissues, - the archiblastic and parablastic. The former includes all the epithelial, muscular, and nervous tissues, comprising, therefore, the glands, smooth muscles, and neuroglia: the parablastic group comprises all the connective tissues and blood, with which are counted the blood and lymph vessels, and also the leucocytes. The parablast arises beyond the embryonic area proper as cells which grow into the embryonic region. These cells arise, according to His, out of the granules of the white yolk; these granules, from cells in the yolk; which cells are immigrated leucocytes, that enter the ovum while it is still in the follicle of the ovary.

Waldeyer accepts this division, but he differs from His mainly in two points, - first, in excluding the lining of the peritoneal cavity from the list of end othelia, and therefore also from the parablast; second, in ascribing a different origin to the parablastic cells. (As regards the first point, there can be no reasonable doubt that His's account of the origin of the membrane is erroneous: because, 1 , the disappearance of the original epithelinm, and the new formation by leucocytes of an epithelium on top of it, was, to the last degree, improbable, so that a gross error of observation would be more probable; $2, \mathrm{His}$ was unable to bring forward any definite observations in his favor; 3 , his conclusion was and has since been contradicted by the direct observations of others. Waldeyer has done good service in calling general attention to these objections, but the matter can hardly be considered new.)

As regards the second point, we reproduce Waldeyer's own summary (p. 47). In the eggs of all animals which have blood and connective tissue at all, the segmentation of the egg does not continue in the same manner up to the end; but one must distinguish a primary and a secondary segmentation: the first divides the egg, so far as it is capable of segmentation, into a number of cells which are mature for the formation of the tissue, and form the primary germinal layers. A remainder of immature segmentation-cells (in holoblastic eggs), or of egg-protoplasm, which has not assumed the cell-form (in meroblastic eggs), is left over. In either form, this remainder does not directly enter into the germ-layers as an integral component, but undergoes first a further cellformation, - the secondary segmentation. From the cells thus formed, the parts richer in protoplasm are cut off, and make the primitive parablast-cells; while the part richer in yolk remains only to be used as nutritive material. It will be seen that the essence of Waldeyer's theory is, that a portion of the segmenting egg is retarded by the presence of yolk; and so there are some cells, or, in meroblastic eggs, some protoplasm, which is laggard in development, and does not directly enter into the primitive layers, but becomes the parablast.

The parablast is essentially identical with the mesenchyma of the brothers Hertwig, except that the latter include the smooth muscles in the group. Waldeyer endeavors to justify his theory of the origin of these tissues from laggard cells, but it seems to the reporter unsuccessfully.

There is given also, p. 38-44, a discussion of the relation of the yolk to cleavage, in which the views advanced several years ago by Minot (Proc. Bost. soc. nat. hist., xix.) are brought forward anew, apparently without knowledge of their previous publication by another writer. In the discussion of the origin of the parablast-cells, p. 9-27, it appears that His's view of their origin from the white yolk is definitely shown to be untenable. Incidentally, emphasis is laid upon the fact, that, in meroblastic eggs, the protoplasm of the animal pole sends down processes into the yolk: it is from these processes in the 'keimwall' of birds' eggs that the parablast-cells arise, according to Waldeyer. His article, as a whole, is chiefly a discussion of the literature of his subject. C. S. Minot.

\section{THE ECLIPSE OF 1882.}

AT the present time, when interest is chiefly drawn toward the successes of the astronomers who observed the eclipse of the sun month before last from the small islands in the Pacific Ocean, the results of the eclipse of May 17, 1882, obtained in Egypt, have especial significance. These were briefly stated by Dr. Schuster at a late meeting of the Royal astronomical society. During the progress of the eclipse three photographic instruments were at work: one took photographs of the corona itself; a second was a photographic camera with a prism placed in front of it, that is, a spectroscope without a collimator; and the third was a complete spectroscope. Photographs were obtained in all three instruments. The direct photographs of the corona indicate its variations from eclipse to eclipse, - a matter of much importance in solar physics. If the photographs taken during eclipses in the past twenty years are compared with each other, it will be seen that the corona varies in a regular way with the state of the sun's surface, although there are irregular minor changes. At the sun-spot minimum the corona is much more regular than at the maximum. At the minimum there is a large equatorial extension, and near the solar poles a series of curved rays. At the maximum there is practically no regularity at all: the long streamers go up sometimes in one direction, and sometimes in another; and this last year, near the sun-spot maximum, there was absolutely no symmetry in the appearance of the corona. The transparency of the streamers was most striking. One streamer can sometimes be traced through another, showing that the matter, whatever it is, must be very thin. The rifts start from the solar surface in an entirely 